\title{
Foliar spray application of glucosinolates and essential oils on processing tomato in open field production system
}

\author{
Catello Pane $^{1^{*}}$, Domenico Rongai ${ }^{2}$, Massimo Zaccardelli ${ }^{1}$ \\ ${ }^{1}$ Consiglio per la Ricerca e la Sperimentazione in Agricoltura, Centro di Ricerca per l'Orticoltura, Salerno, Italy; \\ *Corresponding Author: catello.pane@entecra.it \\ ${ }^{2}$ Consiglio per la Ricerca e la Sperimentazione in Agricoltura, Centro di Ricerca per la Patologia Vegetale, Roma, Italy
}

Received 5 January 2013; revised 17 February 2013; accepted 23 February 2013

\begin{abstract}
The development of new strategies of integrate pest management to improve processing tomato yield and sustainable quality, are requested by the market. This study was carried out to evaluate the effects of foliar applications of glucosinolates and certain medicinal plant essential oils in open field cultivation management. Tomato yield from plots treated with rosemary oil and glucosinolates resulted, on average, significantly higher, until $28 \%$, than that of the control plots. However thyme and oregano oil treated plots showed statistically lower values. Plant vegetative status, including phytosanitary aspects, had the same trend as the production as showed by the exponential regression between two parameters. Findings allow us to conclude that foliar spray of glucosinolates and rosemary essential oils prove to be highly effective treatments inducing increases of tomato yield through plant health improvement.
\end{abstract}

Keywords: Foliar Applications; Integrate Pest Management; Natural Pesticides; Seed Meal; Sustainable Agriculture

\section{INTRODUCTION}

Tomato is a commercially important and most popular annual vegetable crop throughout the world because it is largely required by the market of the fresh and processing industry. Since demand for canned tomatoes is continuously increasing, field production for processing is predominant. In Italy, for example, cultivated areas dedicated to canned tomatoes is around 84,000 hectares against the 19,500 ones invested for fresh consumption, for a harvested total yield of more than 5.3 million tons [1]. Disease and pest management is one of the most important productive factors, since tomato plants are susceptible to a number of important pests and diseases which significantly reduce fruit yield and quality, and eventually causing complete crop loss. When severe biotic epidemics occur, tomato growers generally respond with applications of broad-spectrum chemicals on a calendar basis, with up to 12 to 16 applications per season [2] that weights by $4.1 \%$ on total costs [3]. Due to economic and environmental sustainability needs and since consumers are orienting towards ever more healthy products, reduction of chemical inputs is pursued. In the last years, development of new strategies of integrated pest management (IPM) to improve tomato yield and sustainable quality are requested by producers. For this scope, here foliar treatments with glucosinolates and essential oils are proposed as potential natural pesticides in open field processing tomato cropping systems. Activity and toxicity of these bioactive substances have been well demonstrated against arthropods [4,5], plant pathogens $[6,7]$ and nematodes [8,9]. Glucosinolates are glucosidic compounds characteristic of Brassicas, that release toxicants, mainly isothiocyanates, by action of the enzyme myrosinase in the presence of water [10]. While, essential oils are stem distilled of medicinal plants, belonging to the family Lamiaceae, in which terpenes and phenoles are the major responsible for biocide activity [11]. The aim of this paper is to propose the use of glucosinolate containing-tissues from Brassica carinata and essential oils in IPM of tomato cropping systems upon verification of their impact on productive response.

\section{MATERIALS AND METHODS}

\subsection{Experimental Design}

The study was carried-out during the 2010 and 2011 cropping seasons at the experimental farm of the CRAORT located in Battipaglia $\left(40^{\circ} 35^{\prime} 02^{\prime \prime} \mathrm{N} ; 1^{\circ} 58^{\prime} 50^{\prime \prime} \mathrm{E}\right)$, Salerno District, Italy. The trial's field was a clay loam 
soil with the following features: $8.8 \mathrm{~g}$ organic $\mathrm{C} \cdot \mathrm{kg}^{-1}, 1.0$ g Kjeldahl $\mathrm{N} \cdot \mathrm{kg}^{-1}$, $\mathrm{pH} 7.4,34.6 \%$ sand, $36 \%$ silt, $29.4 \%$ clay, in the top $0-0.40-\mathrm{m}$ soil layer. The experimental design was a randomized complete block with plot areas of $6.80 \mathrm{~m}^{2}$ each, replicated three times. Tomato crop was grown on double raw, at distance of $1.7 \times 0.4 \mathrm{~m}$ with a density of 29,410 plants'ha ${ }^{-1}$. Seedling of cultivar Galeon (peeled tomato with determinate growing) were transplanted on May $8^{\text {th }}, 2010$ (Year 1) and on May $16^{\text {th }}, 2011$ (Year 2), and fruits were harvested on August $7^{\text {th }}, 2010$ and on August $12^{\text {th }}, 2011$, respectively. In each plot, tomato cultivation was carried-out, in both years, following the agrotechnical usual for the area, while data concerning minimum and maximum temperature, atmospheric relative humidity and rainfall, were recorded by meteorological station at CRA-ORT of Battipaglia.

Weekly, aerial treatments consisting of: traditional insecticides and fungicides (Chemicals), Glucosinolates water suspension (Glucosinolate A), Glucosinolates water suspension with mineral oil as coadjuvant (Glucosinolate B), Glucosinolate-based formulate (Glucosinolate C), water emulsion $1 \%$ essential oil of Rosmarinus officinalis L. (Rosemary oil), Thymus vulgaris L. (Thyme oil), Origanum vulgare L. (Oregano oil), Carum carvi L. (Caraway oil) and Melissa officinalis L. (Melissa oil), were compared to non treated plots (Control). Glucosinolates were administered as water suspension of $B$. carinata seed meal $\left(10 \mathrm{~g} \cdot \mathrm{L}^{-1}\right)$. This meal is an industrial by-product that originates by grinding exhausted $B$. carinata seeds [12] that follow the extraction of oil used for transesterification [13].

At harvest, total and marketable yield, weight, rotten, rot tipped and viral damaged on ripe fruits, were determined in an assay area of $4.08 \mathrm{~m}^{2}$ for each plot.

\subsection{Vegetative Status Indexes}

In order to get a quanti-qualitative measurement of the vegetative state of plants in each plot, at harvest three descriptive indexes were assessed as indicated below. Covering index (CI), describing the ampleness of plant projection on the land surface, was assessed using the following scale: $1=20 \%, 2=40 \%, 3=60 \%, 4=80 \%$ and $5=100 \%$ of total available area per plant. Health index (HI), describing the global plant phytosanitary status, was assessed using the following scale: $1=20 \%$, $2=40 \%, 3=60 \%, 4=80 \%$ and $5=100 \%$ of the plant that did not show any disease symptoms. Finally, luxuriance index (LI), describing the plant vigour, was assessed using the follow scale: $1=20 \%, 2=40 \%, 3=$ $60 \%, 4=80 \%$ and $5=100 \%$ of potential vegetative development of the cultivar. These three indexes were mathematically combined together to normalize, for each plot, the $\mathrm{HI}$ on the base of CI and LI, to get vegetative status index (VSI) with the following formula:

$$
\mathrm{VSI}=\mathrm{HI} \times 1 / 5 \mathrm{CI} \times 1 / 5 \mathrm{LI}
$$

Therefore, VSI can assume values included in 1 - 5 range, just as well as absolute $\mathrm{HI}$.

\subsection{Statistical Analysis}

Data from tomato production and descriptive indexes were processed with the analysis of variance (ANOVA). When the ANOVA was significant $(p \leq 0.05)$, means were separated with Duncan's test. Relation between yield and VSI was performed by inferring logarithmic regression of data set.

\section{RESULTS AND DISCUSSION}

The efficacy of certain essential oils and glucosinolate-based formulates as foliar spray was evaluated on tomato productivity and vegetative status of plants, under field conditions. Biennial trials were conducted under meteorological conditions typical of the area, with only minor variations between the two consecutive years (Figure 1). In 2010, recorded temperatures were higher than in 2011. During cultivation the temperature ranged between $11^{\circ} \mathrm{C}$ and $37^{\circ} \mathrm{C}$ in 2010 , while between $9.5^{\circ} \mathrm{C}$ and $38^{\circ} \mathrm{C}$ in the following year. The average of the maximum and minimum which amounted to $29.2^{\circ} \mathrm{C}$ and $18.6^{\circ} \mathrm{C}$, against in 2010 and $17.5^{\circ} \mathrm{C}$ of the second year. Percentage of relative humidity in atmosphere showed large fluctuations between 100 and 40 in 2010 and 90 and 37 in 2011. In general, concerning $\mathrm{RH} \%$, the climate was drier in 2011 than in the previous year. This was also confirmed by rainfall data. In 2010 , in fact, the rains were more intense and better distributed.

Over two years of experimental trials, on tomato yield a significant variability was observed. As shown in Table 1 , there was a reduction in reference controls by $35 \%$, on

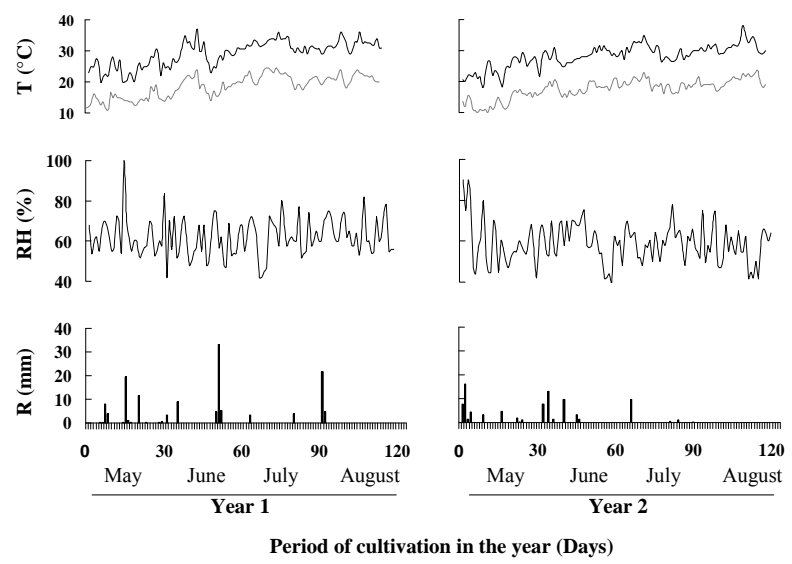

Figure 1. Profiles of atmospheric temperature $(\mathrm{T})$, minimum (grey) and maximum (blak), relative humidity $(\mathrm{RH})$ and rainfall (R) recorded during the period of cultivation in two seasonal trials (years 1 and 2). 
average, over the two successive cultivation seasons. The interaction between year and treatments concerning the productive response, as well as other measured parameters, was significant $(p<0.05)$ as resulted by MANOVA (data not shown). Productive data, distinguished for each year, are presented in Table 1. In the first year, tomato yield of glucosinolates B treated plots were, on average, significantly higher $28 \%$ than that of the control plots. These yields, together those obtained under rosemary oil and glucosinolates A spraying, were statistically comparable respect to control. While thyme and oregano oil treated plots showed statistically lower values. This situation has been largely confirmed in the second year, in which total production of all plots were also statistically comparable to that harvested in chemical treated plots. In this last trial, unfortunately, rosemary oil treatments showed lower yield than control; however, it minimally differed with other treatments in absolute terms. Such contrasting indication may be ascribed to general yield debacle registered in the second year of the experimentation. Marketable production has followed a very similar trend to that of total yield, while significant difference was not found about single fruit weight in both years. These findings indicate the potential of assayed bioactive natural substances to surrogate chemicals in tomato management.

Quality of tomato yield was adversely affected by rotting of berries and rot tip, that were both reduced by treatments with glucosinotates, and by viral damage that, instead, was lower with the use of essential oils (Table 2). These results were in agreement with preliminary investigation that showed the ability of essential oils and glucosinolates to reduce viral symptomatic and rotten fruits [14]. Plant vegetative status as noticed at harvest by cov- ering, health and luxuriance indexes and VSI, had the same trend as the production, showing a decrease in the second year. From the clinical point of view, in fact, the cultivations in the first year showed better features and productivity than those of the second one. Likely, it could be due to difference in climatic behaviour between two trials, in particular, concerning the rains that, in the first year, were abundant and better distributed. Here, health index computed plant parts escaped from pests and fungal diseases that included mainly aphids and moths, Septoria leaf spot, early blight and late blight, respectively. As showed in Table 3, the values of the cited descriptive indexes were highest in plots carriedout under chemical treatments. In the first year, glucosinolates B and rosemary oil treated plants showed covering, health and VSI indexes at statistically comparable levels of those treated by chemicals. While, in the follow year, alternatives to the chemical method do not affected plant indexes. Concerning the luxuriance index, statistically lower values were reported for oregano and melissa oil treatments, in the first year, and for glucosinolates $\mathrm{A}$ and $\mathrm{B}$ and rosemary oil, in the second year. This data indicated that overall glucosinolates B and rosemary oil treatments have excelled in the same way as chemicals. Currently, treatments used here have already shown to be able to control some pests of the tomato, such as CMV aphid-vectored, leaf miner (Tuta absoluta) and rot disease (Phytophthora infestans) [14]. In a previous report, volatic essential oils were used to reduce thrips-vectored tomato spotted wilt virus incidence, as well as standard insecticide treatments, by $6 \%$ to $51 \%$ of untreated control, although without significant yield increases [2]. While, a recent study proposed some Asteraceae essential oils exhibiting insecticidal and antifungal activity that were

Table 1. Effect of foliar treatments on processing tomato productive response in two seasonal trials (years 1 and 2). Values within a column followed by different letters are significantly different (Duncan's test, $p \leq 0.05$ ).

\begin{tabular}{|c|c|c|c|c|c|c|}
\hline \multirow{3}{*}{ Treatments } & \multicolumn{6}{|c|}{ Productive response } \\
\hline & \multicolumn{2}{|c|}{$\begin{array}{l}\text { Total yield } \\
\left(\text { ton } \cdot \mathrm{ha}^{-1}\right)\end{array}$} & \multicolumn{2}{|c|}{$\begin{array}{l}\text { Marketable yield } \\
\quad\left(\text { ton } \cdot \mathrm{ha}^{-1}\right)\end{array}$} & \multicolumn{2}{|c|}{$\begin{array}{l}\text { Single fruit } \\
\text { (g) }\end{array}$} \\
\hline & Year 1 & Year 2 & Year 1 & Year 2 & Year 1 & Year 2 \\
\hline Control & $78.5 b$ & $48.7 b$ & $74.8 \mathrm{ab}$ & $42.9 \mathrm{ab}$ & 49.7 & 75.3 \\
\hline Chemicals & $99.7 \mathrm{a}$ & $64.6 \mathrm{a}$ & $90.0 \mathrm{ab}$ & $57.0 \mathrm{a}$ & 52.0 & 72.7 \\
\hline Glucosinolates A & $91.3 \mathrm{ab}$ & $51.1 \mathrm{ab}$ & $88.0 \mathrm{ab}$ & $45.9 \mathrm{ab}$ & 49.3 & 70.3 \\
\hline Glucosinolates B & $100.5 \mathrm{a}$ & $55.0 \mathrm{ab}$ & $95.4 \mathrm{a}$ & $49.2 \mathrm{ab}$ & 51.0 & 73.2 \\
\hline Glucosinolates C & $79.5 b$ & $57.9 \mathrm{ab}$ & $83.8 \mathrm{ab}$ & $50.0 \mathrm{ab}$ & 49.3 & 71.3 \\
\hline Rosmary oil & $83.1 \mathrm{ab}$ & $46.6 \mathrm{~b}$ & $80.0 \mathrm{ab}$ & $42.3 b$ & 50.3 & 74.3 \\
\hline Thyme oil & $20.5 \mathrm{c}$ & $53.4 \mathrm{ab}$ & $19.9 \mathrm{c}$ & $47.7 \mathrm{ab}$ & 51.0 & 74.2 \\
\hline Caraway oil & $74.9 \mathrm{~b}$ & $53.0 \mathrm{ab}$ & $71.0 \mathrm{~b}$ & $46.3 \mathrm{ab}$ & 51.7 & 70.5 \\
\hline Melissa oil & $79.5 b$ & $53.4 \mathrm{ab}$ & $74.6 \mathrm{ab}$ & $46.9 \mathrm{ab}$ & 53.0 & 76.7 \\
\hline
\end{tabular}


Table 2. Effect of foliar treatments on number of detected rotten and rot tip fruits and on incidence of viral damaged berries in two seasonal trials (years 1 and 2). Values within a column followed by different letters are significantly different (Duncan's test, $p \leq$ $0.05)$.

\begin{tabular}{|c|c|c|c|c|c|c|}
\hline \multirow{3}{*}{ Treatments } & \multicolumn{6}{|c|}{ Ripe fruits } \\
\hline & \multicolumn{2}{|c|}{ Rotten (n.) } & \multicolumn{2}{|c|}{ Rot tip (n.) } & \multicolumn{2}{|c|}{ Viral damaged (\%) } \\
\hline & Year 1 & Year 2 & Year 1 & Year 2 & Year 1 & Year 2 \\
\hline Control & $61.7 \mathrm{c}$ & $183.3 \mathrm{bc}$ & - & $50.33 \mathrm{a}$ & - & $16.0 \mathrm{~b}$ \\
\hline Chemicals & $58.0 \mathrm{c}$ & $48.33 \mathrm{~d}$ & - & $17.0 \mathrm{ab}$ & - & 26.6ab \\
\hline Glucosinolates A & $64.7 \mathrm{c}$ & $121.3 \mathrm{~cd}$ & - & $9.7 \mathrm{~b}$ & - & $27.7 \mathrm{ab}$ \\
\hline Glucosinolates B & $71.6 \mathrm{bc}$ & $78.0 \mathrm{~d}$ & - & $13.0 \mathrm{~b}$ & - & $37.0 \mathrm{a}$ \\
\hline Glucosinolates C & $70.3 b c$ & $176.0 \mathrm{bc}$ & - & $6.7 b$ & - & $30.3 \mathrm{ab}$ \\
\hline Rosmary oil & $81.33 \mathrm{abc}$ & $219.0 \mathrm{~b}$ & - & $11.3 \mathrm{~b}$ & - & $23.0 \mathrm{ab}$ \\
\hline Thyme oil & $92.0 \mathrm{ab}$ & $360.7 \mathrm{a}$ & - & $18.7 \mathrm{ab}$ & - & $16.6 \mathrm{ab}$ \\
\hline Oregano oil & $105.0 \mathrm{a}$ & $387.0 \mathrm{a}$ & - & $8.6 \mathrm{~b}$ & - & $13.6 \mathrm{~b}$ \\
\hline Caraway oil & $104.3 \mathrm{a}$ & $230.0 \mathrm{~b}$ & - & $9.3 \mathrm{~b}$ & - & $16.7 \mathrm{~b}$ \\
\hline Melissa oil & 93.0ab & $188.3 \mathrm{bc}$ & - & $17.3 \mathrm{ab}$ & - & $15.0 \mathrm{~b}$ \\
\hline
\end{tabular}

Table 3. Effect of foliar treatments on tomato plant status noticed by covering, health and luxuriance index, and by vegetative status index (VSI) in two seasonal trials (years 1 and 2). Values within a column followed by different letters are significantly different (Duncan's test, $p \leq 0.05$ ).

\begin{tabular}{|c|c|c|c|c|c|c|c|c|}
\hline \multirow[b]{3}{*}{ Treatments } & \multicolumn{8}{|c|}{ Tomato Plant Status } \\
\hline & \multicolumn{2}{|c|}{ Covering $(1-5)$} & \multicolumn{2}{|c|}{ Health $(1-5)$} & \multicolumn{2}{|c|}{ Luxuriance (1 - 5) } & \multicolumn{2}{|c|}{ VSI $(1-5)$} \\
\hline & Year 1 & Year 2 & Year 1 & Year 2 & Year 1 & Year 2 & Year 1 & Year 2 \\
\hline Control & $2.9 \mathrm{~b}$ & $2.1 \mathrm{~b}$ & $2.8 \mathrm{~b}$ & $1.8 \mathrm{bc}$ & $4.2 \mathrm{a}$ & $3.7 \mathrm{ab}$ & $1.5 \mathrm{~b}$ & $0.6 \mathrm{~b}$ \\
\hline Chemicals & $4.7 \mathrm{a}$ & $3.7 \mathrm{a}$ & $4.8 \mathrm{a}$ & $3.5 \mathrm{a}$ & $4.3 \mathrm{a}$ & $3.9 \mathrm{ab}$ & $3.9 \mathrm{a}$ & $2.0 \mathrm{a}$ \\
\hline Glucosinolates A & $3.5 b$ & $2.0 \mathrm{~b}$ & $3.4 \mathrm{~b}$ & $1.7 \mathrm{bcd}$ & $3.8 \mathrm{ab}$ & $3.6 \mathrm{~b}$ & $1.9 \mathrm{~b}$ & $0.5 \mathrm{bc}$ \\
\hline Glucosinolates B & $4.0 \mathrm{ab}$ & $1.7 \mathrm{c}$ & $3.8 \mathrm{ab}$ & $1.5 \mathrm{~cd}$ & $4.3 \mathrm{a}$ & $3.6 \mathrm{~b}$ & $2.7 \mathrm{ab}$ & $0.4 b c$ \\
\hline Glucosinolates C & $3.4 \mathrm{~b}$ & $1.7 \mathrm{c}$ & $3.3 \mathrm{~b}$ & $1.5 \mathrm{~cd}$ & $4.2 \mathrm{a}$ & $4.0 \mathrm{a}$ & $1.9 \mathrm{~b}$ & $0.4 \mathrm{bc}$ \\
\hline Rosmary oil & $4.0 \mathrm{ab}$ & $1.5 \mathrm{c}$ & $3.7 \mathrm{ab}$ & $1.4 \mathrm{~d}$ & $4.1 \mathrm{ab}$ & $3.6 \mathrm{~b}$ & $2.5 \mathrm{ab}$ & $0.3 \mathrm{c}$ \\
\hline Thyme oil & $3.5 \mathrm{~b}$ & $1.7 \mathrm{c}$ & $3.1 \mathrm{~b}$ & $1.5 \mathrm{~cd}$ & $3.6 \mathrm{ab}$ & $4.0 \mathrm{a}$ & $1.6 \mathrm{~b}$ & $0.4 \mathrm{bc}$ \\
\hline Oregano oil & $3.1 b$ & $1.7 \mathrm{c}$ & $3.1 \mathrm{~b}$ & $1.6 \mathrm{bcd}$ & $3.1 \mathrm{~b}$ & $4.0 \mathrm{a}$ & $1.3 \mathrm{~b}$ & $0.4 b c$ \\
\hline Caraway oil & $3.5 b$ & $1.5 \mathrm{c}$ & $3.5 \mathrm{~b}$ & $1.5 \mathrm{~cd}$ & $3.5 \mathrm{ab}$ & $3.8 \mathrm{ab}$ & $1.9 \mathrm{~b}$ & $0.3 \mathrm{c}$ \\
\hline Melissa oil & $3.1 \mathrm{~b}$ & $2.0 \mathrm{~b}$ & $3.1 \mathrm{~b}$ & $1.9 \mathrm{~b}$ & $3.1 \mathrm{~b}$ & 3.8ab & $1.5 \mathrm{~b}$ & $0.6 \mathrm{~b}$ \\
\hline
\end{tabular}

exploitable to manage tomato crop affected by many insects and fungal diseases, including Trialeurodes vaporariorum and Tuta absoluta, and the fungi Alternaria spp. and Botrytis cinerea [15].

Since these eco-friendly plant-derived products, generally, possess a broad spectrum of activity against several pathogens and pests [7,16,17], health index can prove to be a well parameter to measure the treatment efficacy on the base of plant protecting ability, especially in the absence of specific adversities. Actually, this can be true since field conditions, by definition, may be quite variable and outbreak occurrences are not easily predictable. Recently it was reported that $B$. carinata seed meal used as biofumigant incited a statistically significant increment of lettuce yield under natural conditions in which, however, disease occurred very rarely [18]. Here, the VSI influences positively, with an exponential behaviour, the productivity of the tested system (Figure 2). This suggests that foliar treatments could affect tomato yield by protecting plants and by ensuring them a harmonious and complete development. A previous field study gained the same conclusions. Application of carnation, caraway and thyme essential oils as foliar spray in potato trials prove to be highly effective treatments inducing increases of tuber yield by improving plant health [19]. 


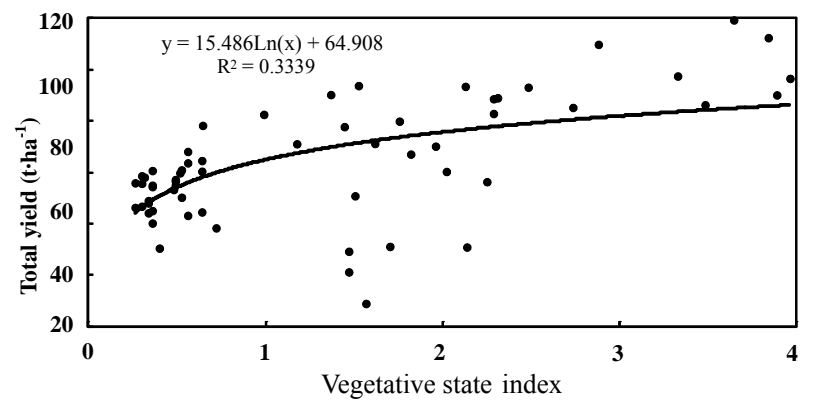

Figure 2. Logarithmic regression between total yield and vegetative state index.

In conclusion, glucosinolates and essential oils, particularly those distilled from rosemary plants, give good perspective concerning their utilization in integrate pest management of processing tomato cropping systems. Nevertheless, it is necessary a lower variability in the productive response to treatments. Further studies will allow progress to be made on this point.

\section{AKNOWLEDGEMENTS}

This research was supported by the "Extravalore" Project, funded by the Italian Ministry of Agricultural, Food and Forestry Policies.

\section{REFERENCES}

[1] Istat (2011) Italian National Statistics Institute, Agricoltura e Zootecnica. www.istat.it

[2] Reitz, S.R., Maiorino, G., Olson, S., Sprenkel, R., Crescenzi, A. and Momol, M.T. (2008) Integrating plant essential oils and kaolin for the sustainable management of thrips and tomato spotted wilt on tomato. Plant Disease, 92, 878-886. doi:10.1094/PDIS-92-6-0878

[3] Engindeniz, S. (2006) Economic analysis of pesticide use on processing tomato growing: A case study for Turkey. Crop Protection, 25, 534-541. doi:10.1016/j.cropro.2005.08.009

[4] Paluch, G., Bessette, S. and Bradbury, R. (2011) Development of essential oil-based arthropod repellent products. In: Recent Developments in Invertebrate Repellents, ACS Symposium Series, Chapter 10, Washington DC, 151-161.

[5] Tsao, R., Reuber, M., Johnson, L. and Coats, J.R. (1996) Insecticidal toxicities of glucosinolate-containing extracts from crambe seeds. Journal of Agricultural Entomology, 13, 109-120.

[6] Lalitha, V., Kiran, B. and Raveesha, K.A. (2011) Antifungal and antibacterial potentiality of six essential oils extracted from plant source. International Journal of Engineering Science and Technology, 3, 3029-3037.

[7] Galletti, S., Sala, E., Leoni, O., Burzi, P.L. and Cerato, C. (2008) Trichoderma spp. tolerance to Brassica carinata seed meal for a combined use in biofumigation. Biological Control, 45, 319-327. doi:10.1016/j.biocontrol.2008.01.014

[8] Oka, Y., Nacar, S., Putievsky, E., Ravid, U., Yaniv, Z. and Spiegel, Y. (2000) Nematicidal activity of essential oils and their components against the root-knot nematode. Phytopathology, 90, 710-715. doi:10.1094/PHYTO.2000.90.7.710

[9] Vaughn, F.S. (1999) Glucosinolates as natural pesticides. In: Cutler, H.G. and Cutler, S.J., Eds., Biologically Active Natural Products Agrochemicals, CRC Press LLC, Boca Raton. doi:10.1201/9781420048629.ch7

[10] Brown, P.D. and Morra, M.J. (1997) Control of soil-borne plant pests using glucosinolate-containing plants. Advances in Agronomy, 61, 167-231. doi:10.1016/S0065-2113(08)60664-1

[11] Isman, M.B. (2000) Plant essential oils for pest and disease management. Crop Protection, 19, 603-608. doi:10.1016/S0261-2194(00)00079-X

[12] Cardone, M., Mazzoncini, M., Menini, S., Rocco, V., Senatore, A., Seggiani, M. and Vitolo, S. (2003) Brassica carinata as alternative oil crop for the production of biodiesel in Italy: Agronomic evaluation, fuel production by transesterification and characterization. Biomass and Bioenergy, 25, 623-636. doi:10.1016/S0961-9534(03)00058-8

[13] Gasol, C.M., Gabarrell, X., Anton, A., Rigola, M., Carrasco, J., Ciria, P., Solano, M.L. and Rieradevall, J. (2007) Life cycle assessment of a Brassica carinata bioenergy cropping system in southern Europe. Biomass and Bioenergy, 31, 543-555. doi:10.1016/j.biombioe.2007.01.026

[14] Zaccardelli, M. and Campanile, F. (2011) Use of essential oils and glucosinolates to control insects and viral damages on tomato cultivated in open field. Acta Horticulturae, 914, 397-399.

[15] Umpiérrez, M.L., Lagreca, M.E., Cabrera, R. and Grille, G. (2012) Essential oils from Asteraceae as potential biocontrol tools for tomato pests and diseases. Phytochemistry Review, in press. doi:10.1007/s11101-012-9253-5

[16] Bakkali, F., Averbeck, S., Averbeck, D. and Idaomar, M. (2008) Biological effects of essential oils-A review. Food and Chemical Toxicology, 46, 446-475. doi:10.1016/j.fct.2007.09.106

[17] Monfort, W.S., Csinos, A.S., Desaeger, J., Seebold, K., Webster, T.M. and Diaz-Perez, J.C. (2007) Evaluating Brassica species as an alternative control measure for root-knot nematode ( $M$. incognita) in Georgia vegetable plasticulture. Crop Protection, 26, 1359-1368. doi:10.1016/i.cropro.2006.11.008

[18] Pane, C., Villecco, D., Pentangelo, A., Lahoz, E. and Zaccardelli, M. (2012) Integration of soil solarization with Brassica carinata seed meals amendment in a greenhouse lettuce production system. Acta Agriculturae Scandinavica-Section B Soil and Plant Science, 62, 291-299.

[19] El-Mougy, N.S. (2009) Effect of some essential oils for limiting early blight (Alternaria solani) development in potato field. Journal of Plant Protection Research, 49, 57-62. doi:10.2478/v10045-009-0008-2 